ISSN 1991-8631

Original Paper

http://indexmedicus.afro.who.int

\title{
Microbial and physicochemical properties of ground water of Ilaro, South-West, Nigeria
}

\author{
Foluso FAPARUSI ${ }^{1 *}$, Hassan AYEDUN ${ }^{2}$ and Maryam M. BELLO-AKINOSHO ${ }^{1}$

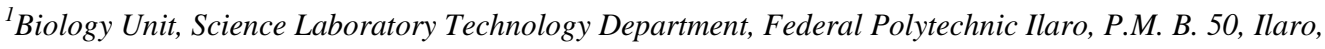 \\ Ogun State, Nigeria. \\ ${ }^{2}$ Chemistry Unit, Science Laboratory Technology Department, Federal Polytechnic Ilaro, P.M. B. 50, Ilaro, \\ Ogun State, Nigeria. \\ *Corresponding author, E-mail: foluparusi@yahoo.com, Tel: 234-8057896944, 234-8061135681.
}

\begin{abstract}
The present study was carried out to determine the microbial quality and physicochemical properties of ground water in Ilaro, a semi-urban settlement. Plate count agar (PCA), MacConkey broth and eosin methylene blue agar (EMB) were used in the microbial analysis. The results showed that the most probable number (MPN) ranges from $0-50$ per $100 \mathrm{ml}$ while the total viable count (TVC) ranged from $0.07 \times 10^{2}-4.12 \times 10^{2}$ cfu $\mathrm{ml}^{-1}$. Bacillus subtilis, Bacillus cereus, Staphylococcus aureus, Streptococcus faecalis, Escherichia coli, Enterobacter aerugenosa and Micrococcus luteus were isolated. The physicochemical properties measured using their respective meters showed that the water was acidic. It was concluded that treatment before consumption is necessary to avoid borne diseases.

(C) 2011 International Formulae Group. All rights reserved.
\end{abstract}

Key words: Bacteria, chemical parameters, quality, drinking water,

\section{INTRODUCTION}

Water is one of the most important and most precious natural resources. It is essential in the life of all living organisms from the simplest plant and microorganisms to the most complex living system known as human body (Onifade and Ilori, 2008). Moreover, while living things may exist for a considerable time without other essential nutrient, they soon die without water. The protoplasm of most living cells contains about $80 \%$ water and any substantial reduction in this percentage is disastrous. All living organisms require a wide variety of inorganic compounds for growth, repair, maintenance and reproduction. Water is one of the most important as well as one of the most abundant of these compounds and vital to organisms (Tortora et al., 2002). Ground water is a complex chemical solution which is in dynamic state, the composition of which to a large extent is attributable to the solution of material in soil and rocks by percolation and partly to chemical reaction between this water and the host medium. Ground water exists within earth's surface and become borehole water when pumped or conveyed to the surface via a network of pumps. It is an important source of drinking 
water in African towns and cities; the quality of this resource is often being compromised because of urbanization and combined use of aquifers as a repository for human waste (Cronin et al., 2006, 2007; Taylor et al., 2004). The Household, commercial and industrial wastes that end up in dumps, wastes lagoons, or septic systems often pollute ground water. Residential areas with septic systems usually add nitrate nitrogen, bacteria, viruses and synthetic organics used in household (Arnade, 1999; Cronin et al., 2007). The most dangerous form of water pollution occurs when faecal contaminant like Escherichia coli enters the water supply. Pathogens such as Salmonella spp., Shigella, Vibrio cholerea and Escherichia coli that are shed into water body through faecal contamination perpetuate many diseases. Since ground water moves slowly, many years may pass before a pollutant released on the land surface above the aquifer is detected in water taken from the aquifer some distance away. Soil type, pore size, porosity, season and water table level play important roles in ground water pollution (Arnade, 1999; Cheung and Venkitachalam, 2004). Unfortunately, contamination is often widespread before detected. In evaluation of any ground water resources, the quality and quantity is most importance. In other words, the chemical, physical and biological characteristics of water are of major importance in determining whether or not the water is suitable for domestic, industrial or agricultural use (Okonko et al., 2008; Okonko et al., 2009; Onifade and Ilori, 2008). Recently, there is growing awareness of impact on the environment of effluents and solid wastes of anthropogenic origin (Obahiagbo and Okiemen, 2007).

In many developing countries, availability of potable water has become a critical and urgent problem. It is a matter of great concern to families and communities depending on non-public water supply system. Conformation with microbiological standard is of special interest because of the capacity of water to spread disease with a large population. The objective of this study was to assess the microbiological quality and physiochemical properties of ground water in Ilaro.

\section{MATERIALS AND METHODS}

\section{The study area}

Ilaro is a semi- urban settlement located in western part of Ogun State, South-West Nigeria. It has been the head quarters of Egbado South local government since 1976. The inhabitants are predominantly farmers, traders, staff of the Federal polytechnic and Civil Servants. Ground water samples were collected from different locations in Ilaro, Ogun state, Nigeria. The research was conducted between November 2009 and April 2010 , for a period of six months.

\section{Method}

Ground water samples were collected from different locations in Ilaro, Ogun State, Nigeria and were analysed within 4 hours of collection. Physicochemical and bacteriological analyses were carried out according to methods of FAO (1997) and Okonko et al. (2008). The pH was measured with a pH meter (potable model 200VWR scientific) and the conductivity was measured with Thermo Orion model 105 after standardizing with $\mathrm{KCl}$ and $\mathrm{NaCl}$ solution. The $\mathrm{pH}$ meter was calibrated with buffers 4 and 9 before use while the chlorines were determined using Morh's method (Greenberg et al., 1992). Geographical positioning satellite (GPS) Extrex legend model was used to determine the position of each ground water. Temperature was measured at the point of collection using a digiton Thermometer (model 275-K) as described by FAO (1997) and Okonko et al. (2009). The media used for the bacteriological analyses were plate count agar (PCA), Mac Conkey broth and eosin methylene blue agar (EMB). The required amounts of the media were weighed and prepared according to the manufacturer's instructions. Plate count agar was used for 
total viable count (TVC), MacConkey broth for the presumptive test and eosin methylene blue agar was used for confirmed test. Standard of Okonko et al. (2009) was adopted while uninoculated plates and tubes served as controls. The pure isolates obtained were identified using morphological and biochemical tests as described by Holt et al. (1994).

\section{RESULTS AND DISCUSSION}

The physicochemical properties of ground water samples collected from Ilaro, South-West Nigeria, are shown in Table 1. The locations where the samples were collected are also shown in Table 1. The $\mathrm{pH}$ ranged from $3.41-5.38$. Lowest $\mathrm{pH}$ value was recorded in sample AKU and the highest in sample EXP. The $\mathrm{pH}$ values indicate that the water is highly acidic. All the water samples had $\mathrm{pH}$ values less than IARC (1980) recommended values for drinking water and lower than the values recorded in previous studies of Ayedun et al. (2009). The reason for it may be due to different sampling period or release of trace element from the rocks into the ground water over a period of time. The temperature values ranged from $29.4-43.9{ }^{\circ} \mathrm{C}$ with a mean of $31.6{ }^{\circ} \mathrm{C}$. Water at high temperature contains less dissolved gases (Yusuf, 2007). The temperature of water from subterranean springs is less affected by seasonal variation of temperature (Ipinmoroti, 1993). The alkalinity ranged between $60 \mathrm{mg} \mathrm{l}^{-}$ ${ }^{1} \mathrm{CaCO}_{3}$ and $400 \mathrm{mg} \mathrm{l}^{-1} \mathrm{CaCO}_{3}$. The lowest alkalinity was recorded in sample FPI and the highest in sample AKU. Alkalinity indicates the level of carbonates, bicarbonate and hydroxyl group in water sample but the hydroxyl group is not common to natural water. The low alkalinity is similar to what was reported by Yusuf (2007). Chlorine of the samples ranged from $1.82-125.73 \mathrm{mg} \mathrm{l}^{-1}$. Highest chlorine value was recorded in sample LES and the lowest in samples FPI and $\mathrm{SAB}$. This trend is in variance to what was reported by Fasuwon et al. (2008) but lower than WHO recommended limits. The depth of the wells ranged from 6-68 m (Table 1). The electrical conductivity ranged from $40.8-400 \mu \mathrm{S} \mathrm{cm}^{-1}$, which is far below the recommended limit of $1000 \mu \mathrm{s} \mathrm{cm}^{-1}$ by WHO. Conductivity indicates the presence of dissolved solids and contaminations especially electrolytes but does not give information about specific chemical constituents. The redox potential values ranged from 97- 212 $\mathrm{mV}$. The highest and lowest values were recorded in samples TTD and LESS II respectively. The redox potential shows that the ground water samples were not highly oxidized. The total viable count $\left(\mathrm{cfu} \mathrm{ml}^{-1}\right)$ and most probable number (MPN) of coliform 100 $\mathrm{ml}^{-1}$ of ground water samples in Ilaro, SouthWest, Nigeria is shown in Table 2. The microbial load was different from one sample to another, and ranged from $0.07 \times 10^{2}-4.12$ $\mathrm{x} 10^{2} \mathrm{cfu} \mathrm{ml}^{-1}$. The highest total viable count (TVC) was recorded in sample LES II while sample OTG had the least. Some of the ground water samples fall within standard limit and others exceeded standard limit of 1.0 $\mathrm{x} 10^{2} \mathrm{cfu} 1 \mathrm{~m}^{-1}$. The results corroborate well those of Okonko et al. (2008) on different water samples used for domestic purposes in Lagos and Abeokuta. The most probable number of total coliform count ranged from 0 50 coliform $100 \mathrm{ml}^{-1}$ of ground water sample (Table 1). There was no coliform recorded in samples FPI and OTG, the two samples fall within the recommended standard, while other samples exceeded the limit (Okonko et al., 2008, 2009). Sample LES had the highest total coliform count. The presence of coliform in samples AKU (Akiniku), IGE (Igbo-ewe), LES (Leslie), LES II (Leslie II), ORA (Orita), SAB (Sabo), EXP (Express) and TTD (Tetede-Okeola) indicaltes faecal contamination of ground water, as a result of proximity of the wells and boreholes to septic tanks, soak away and refuse dumping sites (Table not shown). Arnade (1999) reported that there were significant correlations between increasing faecal coliform, nitrate and phosphate concentration and decreasing distance between wells and septic tanks. Soil porosity of the area might also play important roles in the percolation of the contaminated water from the soak away and septic tanks to the wells and bore holes. 
F. FAPARUSI et al. / Int. J. Biol. Chem. Sci. 5(2): 500-506, 2011

Table 1: Physicochemical parameters of ground water samples.

\begin{tabular}{|c|c|c|c|c|c|c|c|c|c|}
\hline $\begin{array}{l}\text { Sample } \\
\text { Code }\end{array}$ & $\mathbf{p H}$ & $\begin{array}{c}\text { Alkalinity (mg/L } \\
\left.\mathrm{CaCO}_{3}\right)\end{array}$ & Tempt. $\left({ }^{\circ} \mathrm{C}\right)$ & $\mathrm{Cl}^{-}(\mathrm{mg} / \mathrm{l})$ & $\mathrm{EC}(\boldsymbol{\mu S} / \mathbf{c m})$ & Depth (m) & $R P(m v)$ & GPS & Location \\
\hline $\mathrm{AKU}$ & 3.94 & 400 & 32.2 & 63.77 & 400 & 11 & 182 & N06 5311.0 E003 0130.1 & Akiniku \\
\hline OTG & 4.53 & 160 & 31.7 & 52.84 & 100 & 15 & 146 & N06 5335.6 E003 0058.6 & Otegbeye \\
\hline LES & 4.05 & 140 & 32.4 & 125.73 & 200 & 9 & 174 & N06 5312.8 E003 0045.5 & Leslie \\
\hline LES II & 3.41 & 100 & 31.9 & 45.55 & 400 & 10 & 212 & N06 5301.5 E003 0037.1 & Leslie 2 \\
\hline ORA & 4.00 & 220 & 29.4 & 12.75 & 200 & 17 & 178 & N06 5302.1 E002 5955.1 & Orita 1 \\
\hline $\mathrm{SAB}$ & 4.59 & 100 & 30.4 & 1.82 & 200 & 6 & 141 & N06 5219.4 E003 0033.1 & Sabo \\
\hline FPI & 5.23 & 60 & 31.2 & 1.82 & 40.8 & 68 & 120 & N06 5314.3 E002 2527.4 & Fed. Poly. \\
\hline EXP & 5.38 & 380 & 31.1 & 14.58 & 342 & 16 & 107 & N06 5333.6 E002 5951.6 & Express \\
\hline TTD & 5.37 & 180 & 34.9 & 56.49 & 41.9 & 6 & 97 & N06 5410.5 E003 0028.8 & Tetede Okeola \\
\hline WH & $6.5-8.5$ & 200 & - & - & 1000 & - & - & - & - \\
\hline
\end{tabular}

Table 2: Total viable count and most probable number (MPN) of coliform per $100 \mathrm{ml}$ of water sample.

\begin{tabular}{lcc}
\hline Sample code & Total viable count & MPN per $\mathbf{1 0 0} \mathbf{~ m l}$ \\
\hline AKU & $0.30 \times 10^{2}$ & 10 \\
IGE & $1.20 \times 10^{2}$ & 2 \\
OTG & $0.07 \times 10^{2}$ & 0 \\
LES & $3.70 \times 10^{2}$ & 50 \\
LES II & $4.12 \times 10^{2}$ & 40 \\
ORA & $2.10 \times 10^{2}$ & 17
\end{tabular}


F. FAPARUSI et al. / Int. J. Biol. Chem. Sci. 5(2): 500-506, 2011

\begin{tabular}{lcc}
\hline SAB & $0.11 \times 10^{2}$ & 4 \\
FPI & $0.12 \times 10^{2}$ & 0 \\
EXP & $0.63 \times 10^{2}$ & 14 \\
TTD & $3.21 \times 10^{2}$ & 35 \\
Standard limit & $1.00 \times 10^{2}$ & NIL \\
\hline
\end{tabular}

Table 3: Distribution of bacterial isolates from different ground water samples.

\begin{tabular}{|c|c|c|c|c|c|c|c|}
\hline Sample code & $\begin{array}{c}\text { Bacillus } \\
\text { cereus }\end{array}$ & $\begin{array}{c}\text { Bacillus } \\
\text { subtilis }\end{array}$ & $\begin{array}{c}\text { Enterobacter } \\
\text { aerogenes }\end{array}$ & $\begin{array}{c}\text { Escherichia } \\
\text { coli }\end{array}$ & $\begin{array}{c}\text { Micrococcus } \\
\text { luteus }\end{array}$ & $\begin{array}{c}\text { Staphylococcus } \\
\text { aureus }\end{array}$ & $\begin{array}{c}\text { Streptococcus } \\
\text { faecalis }\end{array}$ \\
\hline $\mathrm{AKU}$ & + & - & - & - & - & - & - \\
\hline OTG & - & + & - & - & + & - & - \\
\hline LES & + & + & - & + & - & + & - \\
\hline LES II & + & + & - & + & + & - & - \\
\hline ORA & - & - & + & - & - & + & - \\
\hline SAB & - & - & + & - & - & + & - \\
\hline
\end{tabular}


Seasons may play vital roles in the level of contamination of ground water. Arnade (1999) found that inability of septic tank leachate to percolate through the soil during the wet season resulted in ground water contamination thus posing a health risk to those who drink from local well.

The presence of coliforms in most of the ground water samples in this study makes them unfit and unsafe for human consumption (Edema et al., 2001, Okonko et al., 2008, Onifade and Ilori, 2008 and Okonko et al., 2009).

The distribution of bacterial isolates from the different ground water samples is shown in Table 3. Bacillus cereus, Bacillus subtilis, Enterobacter aerogenes, Escherichia coli, Micrococcus luteus, Staphylococcus aureus and Streptococcus faecalis were the organisms isolated. Bacillus sp. was present in all the water samples except samples ORA and SAB. Enterobacter aerogenes was present in samples ORA, SAB and IGE. Escherichia coli was isolated from samples LES II, LES and TTD. Micrococcus lutues was found in samples OTG and LES II. Streptococcus faecalis was recorded only in sample IGE while Staphylococcus aureus was isolated from samples LES, ORA, SAM and EXP The isolation of these bacteria was in agreement with similar works carried out by other researchers (Chao et al., 2004; Okonko et al., 2008; Onifade and Ilori, 2008; Okonko et al., 2009). Isolation of Streptococcus faecalis, Enterobacter aerogenes and Escherichia coli indicates faecal contamination either of human or animal origin, as Escherichia coli is used as an indicator of water borne pathogens (Chao et al., 2004; Onifade and Ilori, 2008). The presence of indicator organisms is an indication that there is high probability of having pathogenic enteric organisms in the water. This might be the source of water borne diseases such as cholera, recently reported in some developing countries. Faecal coliforms, nitrates, and phosphates present in septic effluent are responsible for such diseases as shigellosis, typhoid fever, gastroenteritis, blue baby syndrome (NRC, 1998)

\section{Conclusion}

Bacteriological analyses of the ground water showed that, the total viable count of most of the water samples was too high and the presence of coliform, which make the water unsafe for human consumption. Likewise the physicochemical parameters showed that ground water from the studied areas are acidic and require pretreatment before consumption.

\section{REFERENCES}

Arnade LJ. 1999. Seasonal correlation of well contamination and septic tank distance. Ground Water, 37(6): 920-923.

Ayedun H, Oseni OA, Unaegbu CV, Sotayo MO. 2009. Selected trace metals and physicochemical parameters assessments in groundwater of a fluviatile soil environment. Int. J. Chem. Sci., 2: 54-60.

Chao IO, Chao CC, Chao WL. 2004. Evaluation of colibert-18 for detection of coliforms and Escherichia coli in subtropical freshwater. Appl. J. Environ Microbial., 70: 1242-1244.

Cheung KC, Venkitachalam TH. 2004. Assessment of contamination by percolation of septic tank effluent through natural and amended soils. Environ. Geochem. Health, 26: 157-168.

Cronin AA, Breslin N, Gibson J, Pedley S. 2006. A methodology to prioritise interventions in order to reduce waterborne disease in Northern Mozambique. J. Water Health, 4: 333345.

Cronin AA, Hoadley AW, Gibson J, Breslin N. 2007. Urbanization effects on groundwater chemical quality: Findings focusing on the nitrate problem in 2 African cities reliant on a-site sanitation. J. Water Health, 5: 441-454.

Edema MO, Omemu AM, Fapetu OM. 2001. Microbiological and physicochemical analysis of different drinking water in 
Abeokuta, Nigeria. Nig. J. Microbiol., 11: 57-61.

Fasuwon O, Olowofela J, Akinyemi O, Fasunwon B, Akintokun O. 2008. Contaminants evaluation as water quality indicator in Ago-Iwoye, south-west, Nigeria. Afr. Phys. Rev., 2: 110-116.

Food Agricultural Organisation (FAO), 1997. Chemical Analysis Manual for Food and Water (5th edn). FAO: Rome; 20-26.

Greenberg EA, Clescert LS, Eaton AD. 1992. Standard Methods for Examination of Water and Waste Water (18th edn). American Public Health Association (APHA): Washington, D.C.

Holt JG, Krieg NR, Sneath PHA, Stanley JT, Williams ST. 1994. Bergey's Manual of Systematic Bacteriology (9th edn). Williams \& Wilkins Co.: Baltimore, Maryland; 786.

IARC. 1980. Some metals and metallic compounds. International Agency on Research on Cancer, p. 438. http://openlibrary.org/b/OL21698852M/S ome_metals_and_metallic_compounds

Ipinmoroti KO. 1993. Water quality of shallow well located close to dumping site in Akure, Nigeria. Pak. J. Sci. Ind. Res., 36: 137-141.

National Research Council 1998. Issues in Potable Reuse (1st edn). National Academy Press: Washington.

Obahiagbo KO. Okieimen CO. 2007. Comparison of the levels of some toxic heavy metals in underground water from shallow and deep wells in Nige-Delta. A case study of Warri, Nigerian. J. Chem. Soc. Nig., 32: 28-31.
Okonko IO, Adejoye OD, Ogunnusi TA, Fajobi EA, Shittu OB. 2008. Microbiological and physicochemical analysis of different water samples uses for domestic purposes in abeokuta and ojota, Lagos State, Nigeria. Afr. J. Biotechnol., 7: 617-621.

Okonko IO, Ogunjobi AA, Kolawole OO, Babatunde SIO, Ogunnusi TA, Adejoye OD, Fatobi, EA. 2009. Comparative studies and microbial risk assessment of different water for processing frozen seafoods in Ijora-Olopa, Lagos state, Nigeria. Electr. J. Environ. Agric. Food Chem., 8: 408-415.

Onifade AK, Ilori RM. 2008. Microbiological analysis of sachet water vended in Ondo state, Nigeria. Environ. Res. J., 2: 107110.

Taylor RG, Barrett MH, Tindimugaya C. 2004. Urban Areas of Sub-Saharan Africa: Weathered Crystalline Aquifer System. Urban Groundwater pollution, Lerner DN (ed). Balkema Publishers: Leiden, Netherlands; 155-180.

Tortora GI, Funke BR, Case CL. 2002. Microbiology: An Introduction (8th edn). McGraw-Hill Inc.: United Kingdom, p. 777. ISBN 0-07-122936-1.

Yates MV. 1985. Septic tank density and ground-water contamination. Ground Water, 23(5): 586-591.

Yusuf KA 2007. Evaluation of ground water quality characteristics in Lagos-City. $J$. Applied Sci., 7: 1780-1784. 